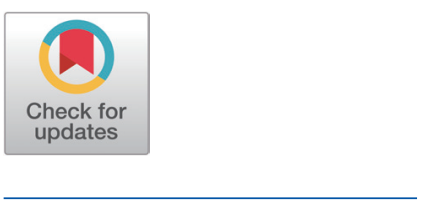

Received: Mar 12, 2021

Revised: Mar 17, 2021

Accepted: Mar 19, 2021

${ }^{*}$ Corresponding author

Younghoon Kim

Department of Agricultural

Biotechnology and Research Institute of Agriculture and Life Science, Seoul National University, Seoul 08826,

Korea.

Tel: +82-2-880-4808

E-mail: ykeys2584@snu.ac.kr

Copyright $\odot 2021$ Korean Society of

Animal Sciences and Technology.

This is an Open Access article

distributed under the terms of the

Creative Commons Attribution

Non-Commercial License (http://

creativecommons.org/licenses/by-

$\mathrm{nc} / 4.0 /$ ) which permits unrestricted

non-commercial use, distribution, and

reproduction in any medium, provided

the original work is properly cited.

ORCID

Dong-Hyun Lim

https://orcid.org/0000-0002-8575-0198

Tae-ll Kim

https://orcid.org/0000-0003-0532-6010

Sung-Min Park

https://orcid.org/0000-0001-9534-0216

Kwang-Seok Ki

https://orcid.org/0000-0003-0971-1389

Younghoon Kim

https://orcid.org/0000-0001-6769-0657

Competing interests

No potential conflict of interest relevant to this article was reported.

\section{Effects of photoperiod and light intensity on milk production and milk composition of dairy cows in automatic milking system}

\author{
Dong-Hyun Lim ${ }^{1}$, Tae-II Kim ${ }^{1}$, Sung-Min Park ${ }^{1}$, Kwang-Seok Ki ${ }^{1}$ and \\ Younghoon $\mathrm{Kim}^{2 *}$ \\ ${ }^{1}$ Dairy Science Division, National Institute of Animal Science, Rural Development Administration, Cheonan \\ 31000, Korea \\ ${ }^{2}$ Department of Agricultural Biotechnology and Research Institute of Agriculture and Life Science, Seoul \\ National University, Seoul 08826, Korea
}

\begin{abstract}
The purpose of this study was to determine the effects of photoperiod and light intensity on milk production, milk composition, hormones levels and blood metabolites indices of Korean Holstein dairy cows in automatic milking system (AMS). A total of 24 Holstein dairy cows were selected and used to four subsequent treatments for the experimental periods of 60 days. The light programs consisted of (1) Control: the natural photoperiod with $14.2 \mathrm{~h}$ of the light period and $9.4 \mathrm{~h}$ of the dark period (below $10 \mathrm{Lux}$ ); (2) T1: $16 \mathrm{~h}$ of the long day photoperiod (LDPP) with 50 Lux of light; (3) T2: 16 h of LDPP with 100 Lux of light; and (4) T3: 16 h of LDPP with 200 Lux of light, respectively. Importantly, there was a significant difference in the thurl activity of dairy cows between the different light intensity programs $(p<0.05)$. Milk yield was higher in T1 and T2 (40.80 \pm 1.71 and $39.90 \pm 2.02 \mathrm{~kg} / \mathrm{d}$, respectively) than those of Control and T3 (32.18 \pm 1.51 and $35.76 \pm 2.80 \mathrm{~kg} / \mathrm{d}$, respectively) $(p<0.05)$, but DMI was lower in T1, T2, and T3 compared to Control $(p<0.05)$. Also, milk fat percentage, the contents of milk fat and total solids were higher in T2 than those in the others $(p<0.05)$. The average daily melatonin level in milk was high to T3 $(28.20 \pm 0.43 \mathrm{pg} / \mathrm{mL}), \mathrm{T} 2(24.62 \pm$ $0.32 \mathrm{pg} / \mathrm{mL}), \mathrm{T} 1(19.78 \pm 0.35 \mathrm{pg} / \mathrm{mL})$, and Control $(19.36 \pm 0.45 \mathrm{pg} / \mathrm{mL})$ in order $(p<0.05)$. Also, the cortisol levels in milk and blood were lower in treatment groups than in Control ( $p$ $<0.05$ ). The results of this study showed that it will be effective to improve the milk yield and milk composition, and to reduce the stress of dairy cows when the light conditions regulate to extend the photoperiod to $16 \mathrm{~h}$ at a light emitting diode (LED) intensity of 100 Lux under the AMS in dairy farm.
\end{abstract}

Keywords: Photoperiod, Light intensity, Automatic milking system, Milk production, Melatonin

\section{INTRODUCTION}

Photoperiod is the time period of daily exposure that an organism receives from daylight or artificial 
Funding sources

This work was supported by the New

Faculty Startup Fund from Seoul National

University (Kim Y) and the Cooperative

Research Program for Agricultural Science

and Technology Development (Project

title: Development of feeding management

technology to increase the melatonin

concentration of milk in dairy cattle; Project

No: PJ01252001) of the Rural Development

Administration of the Korea.

Acknowledgements

Not applicable.

Availability of data and material

Upon reasonable request, the datasets

of this study can be available from the

corresponding author.

Authors' contributions

Conceptualization: Lim DH, Kim TI, Park SM, Ki KS, Kim Y.

Data curation: Lim DH, Kim TI, Park SM, Ki KS, Kim Y.

Formal analysis: Lim DH, Kim TI, Park SM, Ki KS, Kim Y.

Methodology: Lim DH, Kim TI, Park SM, Ki KS.

Software: Lim DH, Kim TI, Park SM, Ki KS.

Validation: Lim DH, Kim TI, Park SM, Ki KS, Kim Y.

Investigation: Lim DH, Kim TI, Park SM, Ki KS, Kim Y.

Writing - original draft: Lim DH, Kim TI, Park SM, Ki KS, Kim Y.

Writing - review \& editing: Lim DH, Kim TI, Park SM, Ki KS, Kim Y.

Ethics approval and consent to participate All dairy cows were maintained as stated in standard guideline, and the experimental protocol involved in this experiment was approved by the Institutional Animal Care and Use Committee (IACUC) at NIAS (study approval number: IACUC 2017-252). light. The photoperiod length has a clear physiological response to reproduction, growth, lactation and health [1]. The intensity of illumination is also known to affect both behavior and physiology of cows [2-5]. Some studies reported that an extended photoperiod could result in an increased milk yield compared to a short photoperiod [6,7]. Cows exposed to long photoperiod have an increased milk production by $5 \%$ to $15 \%$ compared to cows held in short photoperiod [6,8-10]. However, there was no effect on milk yield of dairy cows exposed to lighting for 24-h compared to a natural photoperiod [11]. Phillips and Schofield [12] reported that cows exposed to 481 Lux increased dry matter intake (DMI), milk yield and the time of social activities, while cows exposed to the natural light intensity reduced the lying time. The automatic milking system (AMS) was first introduced into Korea in 2006 [13]. The AMS is in use for $24 \mathrm{~h}$ and are based on voluntary visits to the milking unit several times a day [14]. It has the advantage of freeing dairy farmers from labor and time constraints, a greater milk yield and the ability to collect various information on lactating dairy cattle, compared to conventional milking system (CMS) $[13,14]$. In contrast to these advantages, previous studies have been conducted on stress in dairy cows milked in barns with an AMS [1518]. To facilitate cows' visits to the AMS throughout the night, most dairy farmers provide artificial lighting in the waiting area in front of the AMS and in the AMS unit [19]. The number of milking increases when sufficient illumination is maintained compared to guiding light in the barn at night [3], and then a more frequent milking can enhance milk production [20]. On the other side, the exposure to continuous light in the dark period does not have an effect on milk production of dairy cows [11].

Recently, dairy farmers are seeking the management strategy using lighting tool because this approach might be more safe, non-invasive, and effective method to increase milk yield [21-23]. However, what light period and light intensity that is suitable to maximize the milk yield in Korean dairy farms with AMS is not yet fully studied. The proper light conditions for dairy cows, which are housed in AMS, are very important, as showed many studies that light affects the physiology and behavior of cows. Therefore, this study was performed to evaluate the effects of photoperiod and light intensity on milk production and composition. Also, it was investigated to determine the variation on the activity, hormone and biochemical indices of dairy cows during different light conditions.

\section{MATERIALS AND METHODS}

\section{Animals, experimental design and feeding management}

The experiment was carried out at Department of Animal Resources Development, National Institute of Animal Science (NIAS; Cheonan, Korea). All dairy cows were maintained as stated in standard guideline, and the experimental protocol involved in this experiment was approved by the Institutional Animal Care and Use Committee (IACUC) at NIAS (study approval number: IACUC 2017-252). A total of 24 multiparous Holstein lactating dairy cows (mean \pm SD, $2.4 \pm$ 0.34 parity) were selected with the average days in milk (DIM) $114 \pm 44$ DIM, the 7-d milk yield before starting the study was $35.20 \pm 1.76 \mathrm{~kg} / \mathrm{d}$, the average body weight (BW) $738.2 \pm 19.7 \mathrm{~kg}$, and experiment carried out from May to June 2018. Cows were subjected to the same management procedures and housed in a loose barn. The barn was designed with AMS (Astronaut A3, Lely Industries N.V., Maassluis, the Netherlands) and was modified to control light exposure. All cows had permission to enter the AMS every $4 \mathrm{~h}$ or if cows visiting to AMS within $4 \mathrm{~h}$ after milking were directly sent to the barn area without letting her stay in the AMS.

Dairy cows were allocated to four subsequent experimental treatments. The treatments were different to the light conditions; (1) Control: the natural photoperiod, which was average $14.2 \mathrm{~h}$ 
of the light period and $9.4 \mathrm{~h}$ of the dark period (below 10 Lux under natural conditions); (2) T1: the long day photoperiod (LDPP) was extended to light with intensity of $50 \mathrm{Lux}$ (48.5 $\pm 4.7 \mathrm{Lux}$ ); (3) T2: with intensity of $100 \mathrm{Lux}(104.4 \pm 6.7 \mathrm{Lux})$; (4) T3: with intensity of $200 \mathrm{Lux}(202.8 \pm$ 9.4 Lux), respectively. T1, T2, and T3 groups extended the photoperiod by turning on the light emitting diode (LED) at from 04:30 to 07:00 $\mathrm{h}$ and 18:00 to 20:30 h. Cows for each treatment group control were exposed to natural light without artificial light or LED light. Cows for LDPP treatment were acclimated to particular light intensity types for 10 days before initiating each treatment period of 5 days. Milk and blood samples were collected at each milking during the period of each experimental treatment.

The nutrient content of the concentrate and total mixed ration (TMR) samples were analyzed by Foundation of Agri. Tech. Commercialization \& Transfer (Iksan, Korea). All samples were analyzed by AOAC [24] for concentrations of moisture, crude fiber, ether extract, crude fiber and crude ash, and by Van Soest et al. [25] for concentrations of neutral detergent fiber (NDF) and acid detergent fiber (ADF). Total digestible nutrients (TDN), and net energy for lactation (NEL) were calculated with the equations proposed by the NRC [26].

All dairy cows fed the same total dietary nutrient provision when considering the sum (NEL1.7 $\mathrm{Mcal} / \mathrm{kg}$, and TDN 68.7\%) of the total mixed rations and the AMS concentrate. Total mixed ration (TMR) was offered once a day at 09:00 $\mathrm{h}$ for ad libitum intake, and were fed concentrates according to the milk yield of each cow in the special feeder when were milked. The dry matter intake (DMI, $\mathrm{kg} / \mathrm{d}$ ) was estimated at the herd level for each group daily as the difference between the amount of feed intake and feed refusal. The chemical composition of the rations based on the realized TMR and concentrate are presented in Table 1.

\section{Measurement of temperature humidity index (THI)}

The measurement of ambient temperature $\left({ }^{\circ} \mathrm{C}\right)$ and relative humidity $(\mathrm{RH}, \%)$ was monitored with a thermo-hygrometer (Testo, model $174 \mathrm{H}$, West Chester, PA, USA) with an accuracy of $\pm 0.5^{\circ} \mathrm{C}$, and $\pm 3 \% \mathrm{RH}$. The thermo-hygrometer was set to record every day per $30 \mathrm{~min}$ and placed about 2 meters apart from the feeding area. The temperature and humidity values were used to calculate several THI values; THI was calculated for each $30 \mathrm{~min}$ temperature and humidity measurement according to the formula: THI $=\left(0.8 \times{ }^{\circ} \mathrm{C}\right)+\left[\mathrm{RH} \% \times\left({ }^{\circ} \mathrm{C}-14.4\right)\right]+46.4$, according to Zähner et al. [27].

\section{Light control and measurement of activity volume}

Lights of T1, T2, and T3 groups were exposed to cows under the long photoperiod treatment (day time $:$ night time $=16: 8 \mathrm{~h}$ ) by LED lamps (AFL0312-40W-57KCP123B, AIRTEC SYSTEM, Suwon, Korea), and controlled by an automatic timer (from 04:30 to 07:00 $\mathrm{h}$ and from 18:00 to 20:30 h). The loose barn $(13 \times 50 \mathrm{~m})$ with AMS was installed as followed: $4 \times 9$ lines, 36 LEDs (Fig. 1). The photo-intensity during the night $(21: 00 \mathrm{~h})$ was measured with a light meter (Testo, model 540, Testo AG, Titisee-Neustadt, Germany) at intervals of two meters in barn and at cow eyes level (90 cm from the floor). Fluorescent and metal halide lights are used as common light sources in dairy facilities [28]. However, this study was used LED light, since its lifespan is approximately 12 times longer than that of fluorescent lights [29]. Recently, the number of farms using LED lights has been increasing as installation costs are reduced and long lifespan can decrease dangerous work to replace lights in high celling of barn.

Neck and thurl activity were measured daily in individual cows with method described by Lim et al. [30]. These activity volumes (unit) were calculated using the pedometer (YAMASA, Tokyo, Japan) attached to neck and thurl part of a cow from 09:00 to 18:00 h. 


\begin{tabular}{|c|c|c|}
\hline Items & Concentrates & TMR \\
\hline \multicolumn{3}{|l|}{ Ingredients ratio (\%, DM) } \\
\hline Concentrate & - & 17.75 \\
\hline Cashew nut meal & - & 8.39 \\
\hline Soybean meal & - & 4.15 \\
\hline Corn silage & - & 29.16 \\
\hline Mixed hay & - & 16.27 \\
\hline Alfalfa & - & 12.71 \\
\hline Timothy & - & 10.58 \\
\hline Bypass fat & - & 0.94 \\
\hline Sodium bicarbonate & - & 0.24 \\
\hline Yeast culture & - & 0.24 \\
\hline Mineral mixture & - & 0.24 \\
\hline Calcium carbonate & - & 0.33 \\
\hline \multicolumn{3}{|l|}{ Nutrient compositions (\%, DM) } \\
\hline Moisture (\%, as fed) & 10.92 & 42.89 \\
\hline Crude protein & 18.96 & 10.72 \\
\hline Ether extract & 4.16 & 3.53 \\
\hline Crude fiber & 4.55 & 14.49 \\
\hline Crude ash & 7.93 & 5.77 \\
\hline Neutral detergent fiber (NDF) & 19.01 & 27.88 \\
\hline Acid detergent fiber (ADF) & 7.35 & 16.14 \\
\hline Calcium & 1.40 & 0.61 \\
\hline Phosphorous & 0.57 & 0.25 \\
\hline NFE (\%) & 53.48 & 22.60 \\
\hline TDN (\%) & 74.18 & 67.70 \\
\hline $\mathrm{NE}_{\mathrm{L}}(\mathrm{Mcal} / \mathrm{kg})$ & 1.70 & 1.54 \\
\hline
\end{tabular}

${ }^{1)}$ Values obtained from Foundation of Agricultural Technology Commercialization \& Transfer (Iksan, Korea).

TMR, total mixed ration; DM, dry matter; NFE, nitrogen-free extract; TDN, total digestible nutrients; $\mathrm{NE}_{\mathrm{L}}$, net energy for lactation.

\section{Sampling and analysis of blood and milk}

The blood sample was collected via jugular venipuncture of each cow at 14:00 h once a week using sterile vacutainer tubes (BD Vacutainer, BD, Franklin Lakes, NJ, USA). The collected blood was centrifuged at $1,000 \times \mathrm{xg}$ for $15 \mathrm{~min}$ at $4{ }^{\circ} \mathrm{C}$. The collected serum was stored at $-20^{\circ} \mathrm{C}$ until analysis. Serum samples were used to analyze the metabolic indices status (Wako Chemicals, Neuss, Germany) by using blood auto-analyzer (Hitachi 7180, Hitachi, Tokyo, Japan).

During the experimental period, the milk yield was recorded every day with AMS, and milk samples of each cow collected for $24 \mathrm{~h}$. The collected milk was used to analyze milk fat, protein, lactose, and milk urea nitrogen (MUN) using with LactoScop (MK2, Delta Instruments, Drachten, the Netherlands). Fat and protein corrected milk (FPCM) was calculated according to the formula $\mathrm{FPCM}=(0.337+0.116 \times$ Fat $\%+0.06 \times$ Protein $\%) \times$ milk yield $(\mathrm{kg} / \mathrm{d})$. The biochemical indices of glucose, urea nitrogen (UN), Non-esterified fatty acids (NEFA), total protein, albumin, and triglycerides (TG) level were analyzed with Clinical Analyzer (Hitachi 7180, Hitachi). The cortisol and melatonin concentration of milk and blood were measured using a commercial ELISA kit (Wuhan Abebio Science, Wuhan, China) according to manufacturer's instructions. 


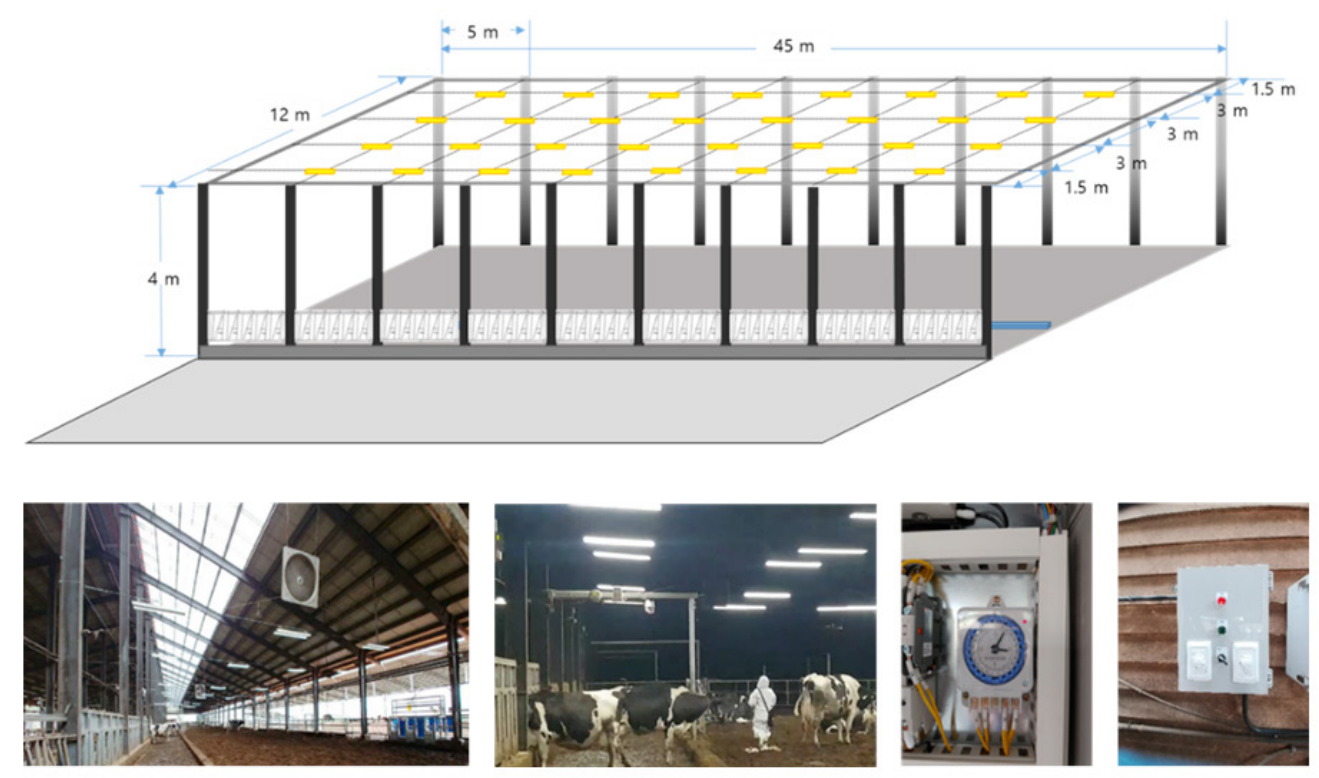

Fig. 1. Schematic layout of barn with LED lights. The photo-intensity during the night (21:00 $\mathrm{h}$ ) was measured with a light meter at intervals of two meters in barn and at cow eyes level ( $90 \mathrm{~cm}$ from the floor). LED, light emitting diode.

\section{Statistical analysis}

The air temperature, RH, THI, and the duration time of day and night were recorded by date. Also, the activity of neck and leg in dairy cow, the feed intake of TMR and concentrates, BW, milk yield, and fat, protein, lactose, and MUN of individual milk were recorded. All the raw data were prepared for Microsoft Excel (Microsoft, Redmond, WA, USA) and then analyzed with the statistical package SAS Enterprise Guide 7.1 (SAS Institute, Cary, NC, USA).

In order to analyze the differences between light period and light intensity within the same analytical parameters, one-way analysis of variance (ANOVA procedure) was applied for all compositions of Control and treatment groups (included 3 groups exposed to 50, 100, and 200 Lux). Also, the effects of milking time and light intensity on melatonin and cortisol concentration of milk were analyzed with multiple analysis of variance (GLM procedure). Statistical relationships were regarded as being significant when the $p$ value was $<0.05$. A multiple comparison test (Tukey Pairwise Comparisons) was performed to differentiate the mean values of treatments when found significant.

\section{RESULTS AND DISCUSSION}

\section{Weather and photoperiod conditions}

Average weather conditions and photoperiod trends during the study period are shown in Fig. 2 and Table 2. The estimated THI values averaged 65.65 per day and increased from May (62.58) to June (68.82) $(p<0.05)$. The average daily air temperature $\left(\mathrm{Ta},{ }^{\circ} \mathrm{C}\right)$ and $\mathrm{RH}(\%)$ were $19.68^{\circ} \mathrm{C}$ and $66.01 \%$, respectively. Ta was increased from May $\left(17.52^{\circ} \mathrm{C}\right)$ to June $\left(21.92^{\circ} \mathrm{C}\right)(p<0.05)$, while $\mathrm{RH}$ was lower in June (64.98\%) than in May (67.31\%) $(p<0.05)$. To date, it has well-established that heat stress during lactation negatively affects milk production. Several studies differently defined on the thermal comfort zone for cows, which Armstrong [31] used THI $<71$, and De Rensis et al. [32] used THI < 68. Compared with the results of these studies, the average THI value of the present study was investigated for environmental conditions that did not cause to heat stress. 
(A)

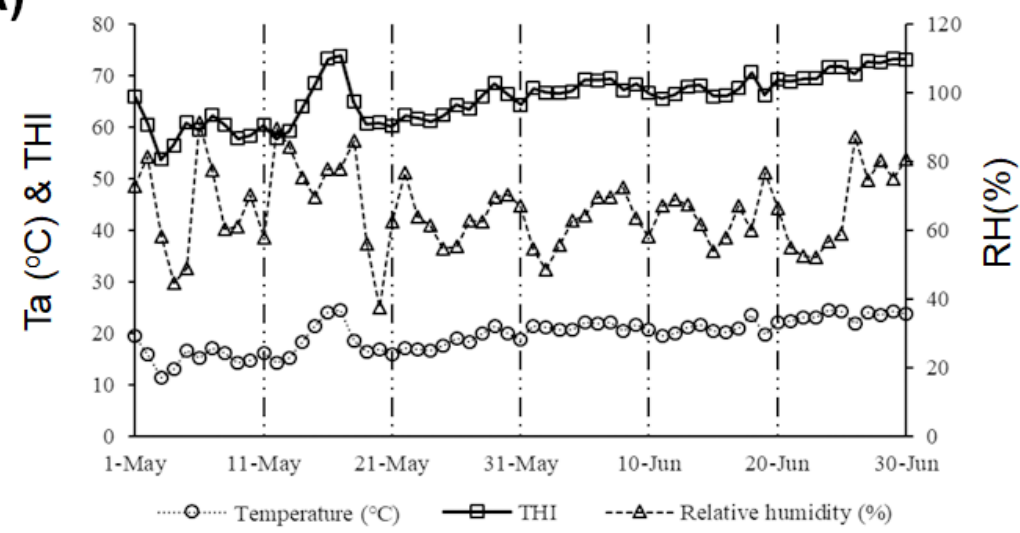

(B)

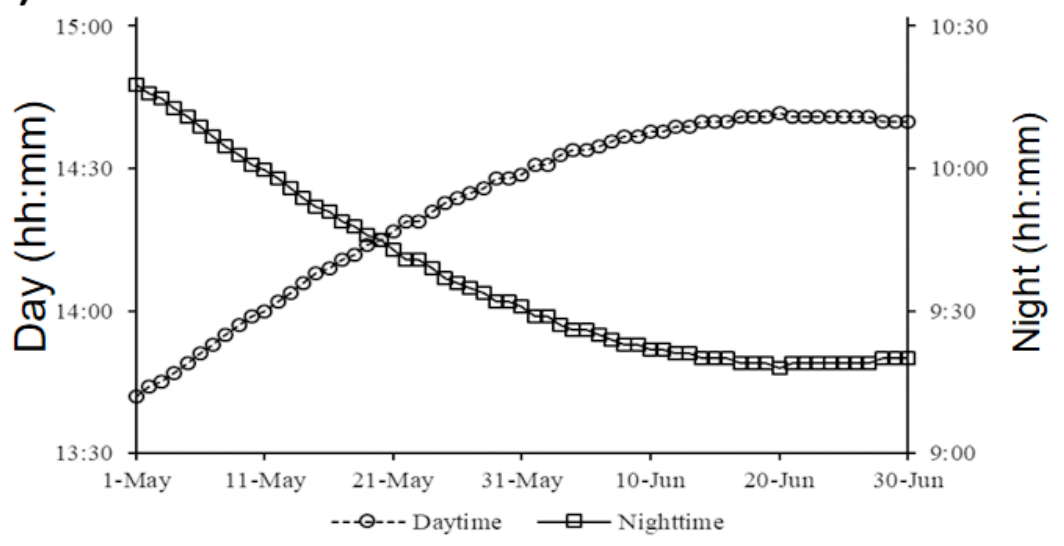

Fig. 2. The average daily value of weather conditions including air temperature, relative humidity, and temperature-humidity index (A), and photoperiod trends (B) from May to June. THI, temperature humidity index.

Table 2. The daily average of air temperature $\left(\mathrm{Ta},{ }^{\circ} \mathrm{C}\right)$, relative humidity $(\mathrm{RH}, \%)$, Temperature-humidity index (THI) and photoperiod during the study period

\begin{tabular}{|c|c|c|c|c|c|}
\hline Item & May & June & Mean & SEM & $p$-value \\
\hline THI & 62.58 & 68.82 & 65.65 & 0.60 & $<0.001$ \\
\hline $\mathrm{Ta}\left({ }^{\circ} \mathrm{C}\right)$ & 17.52 & 21.92 & 19.68 & 0.41 & $<0.001$ \\
\hline $\mathrm{RH}(\%)$ & 67.31 & 64.98 & 66.01 & 1.45 & 0.372 \\
\hline \multicolumn{6}{|l|}{ Photoperiod (hh:mm) } \\
\hline Daytime & $14: 07$ & $14: 38$ & $14: 22$ & 0.00 & $<0.001$ \\
\hline Nighttime & $9: 52$ & $9: 21$ & 9:37 & 0.00 & $<0.001$ \\
\hline
\end{tabular}

In the study period, the daily daytime in June increased by an average of 31 min from May, making the night time in June shorter than in May. Also, the average daytime per day was 14:07 in May and 14:38 in June. Many studies reported that dairy cows exposed to LDPP (16 h of light) have an increased milk production compared to cow exposed to short-day photoperiod (SDPP, 8 $\mathrm{h}$ of light) $[6,9,10]$. Based on these results, treatment groups (T1, T2, and T3) in this study were exposed to the photoperiod (day : night $=16: 8 \mathrm{~h}$ ), which was $2 \mathrm{~h}$ longer than the control of the natural conditions. However, there were concerns about whether the extension of light interfered with the cow's sleeping hours. Cows sleep total $4 \mathrm{~h}$ per day [33], and spend more time sleeping at 
night compared to day time [34]. Therefore, $8 \mathrm{~h}$ of night time for this study was considered as a proper time that did not adversely affect the sleeping time of cows.

\section{Neck and thurl activity}

The activity volume of neck and thurl part in day time from 09:00 to 18:00 h with the photoperiod and light intensity are shown in Table 3 . The mean activity volume of neck during the day time reduced with increasing light intensity from 50 to $200 \mathrm{Lux}$ compared with the Control $(p<0.05)$, and the thurl activity of T1 (370.8 unit) and T2 (361.8 unit) was higher than in that of Control (161.0 unit) and T3 (118.4 unit) ( $p<0.05$ ). Adamczyk et al. [35] reported that mean 24-h activity of cows in early and late lactation remained at a similar level, but appeared to slightly higher relationship between milk yield and activity. In this study, the higher thurl activity of T1 and T2 may be associated with an increase in milk yield, as shown by Adamczyk et al. [35]. Phillips and challengers [4] reported that an optimal level of illumination for walking through the passageways in the dark should be between 39 Lux and 119 Lux. Also, Pettersson and Wiktorsson [3] found that there was no significant difference in cattle preference on the lying area where fully lit or lit with guiding lights only during the dark period.

\section{Dry matter intake, body weight, milk production and milk composition}

The DMI, BW, milk production, and milk composition trends in different light programs are shown in Table 4. Milk yield in this study was higher in longer photoperiod (50, 100, and 200 Lux, $40.80 \mathrm{~kg}, 39.90 \mathrm{~kg}$, and $35.76 \mathrm{~kg}$ per day, respectively) than in natural photoperiod (Control, 32.18

Table 3. Comparative performance on activity volume ${ }^{1)}$ in lactating dairy cows when changing of light intensity

\begin{tabular}{rrrrrrr}
\hline \multicolumn{1}{c}{ Item } & Control & T1 & T2 & T3 & SEM & $p$-value \\
\hline Neck part & $2,904.7^{\mathrm{a}}$ & $2,171.3^{\mathrm{ab}}$ & $1,553.3^{\mathrm{bc}}$ & $1,154.4^{\mathrm{c}}$ & 180.7 & 0.002 \\
Thurl part & $161.0^{\mathrm{b}}$ & $370.8^{\mathrm{a}}$ & $361.8^{\mathrm{a}}$ & $118.4^{\mathrm{b}}$ & 26.1 & 0.001 \\
\hline
\end{tabular}

Control, natural photoperiod; T1, LDPP (day : night $=16: 8 \mathrm{~h}$ ) with 50 Lux of the light intensity; T2, LDPP with 100 Lux; T3, LDPP with 200 Lux.

${ }^{1)}$ Activity volume (unit) was counted using pedometer from 09:00 to 18:00 daily.

${ }^{a-c}$ Denotes comparison made within rows $(p<0.05)$.

Table 4. Dry matter intake, body weight, milk production and milk composition in lactating dairy cows

\begin{tabular}{|c|c|c|c|c|c|c|}
\hline Item & Control & $\mathrm{T} 1$ & T2 & T3 & SEM & $p$-value \\
\hline DMI (kg/d) & $29.03^{a}$ & $27.35^{\mathrm{b}}$ & $26.71^{b}$ & $28.90^{\mathrm{ab}}$ & 0.26 & 0.004 \\
\hline Body weight $(\mathrm{kg})$ & 738.18 & 733.55 & 727.27 & 727.00 & 9.08 & 0.968 \\
\hline $\mathrm{FPCM}^{1)}(\mathrm{kg} / \mathrm{d})$ & $29.99^{c}$ & $37.29^{a b}$ & $39.57^{\mathrm{a}}$ & $33.75^{b c}$ & 0.99 & 0.003 \\
\hline Milk fat (\%) & $3.86^{b}$ & $3.57^{c}$ & $4.35^{\mathrm{a}}$ & $3.70^{\mathrm{bc}}$ & 0.04 & $<0.001$ \\
\hline MUN (mg/100 g) & $14.97^{c}$ & $19.13^{b}$ & $20.29^{a}$ & $20.21^{a}$ & 0.18 & $<0.001$ \\
\hline Milk fat (kg) & $1.15^{b}$ & $1.30^{b}$ & $1.62^{\mathrm{a}}$ & $1.26^{b}$ & 0.05 & 0.005 \\
\hline Milk protein (kg) & 0.99 & 1.18 & 1.21 & 1.08 & 0.04 & 0.143 \\
\hline Lactose (kg) & 1.55 & 1.81 & 1.83 & 1.68 & 0.06 & 0.349 \\
\hline
\end{tabular}

Control, natural photoperiod; T1, LDPP (day : night = $16: 8 \mathrm{~h}$ ) with 50 Lux of the light intensity; T2, LDPP with 100 Lux; T3, LDPP with 200 Lux.

${ }^{1)}$ Calculated by milk yield $\times(0.337+0.116 \times$ Fat $\%+0.06 \times$ Protein $\%)$.

a-c Denotes comparison made within rows $(p<0.05)$.

DMI, dry matter intake; FPCM, fat and protein corrected milk; MUN, milk urea nitrogen. 
$\mathrm{kg} / \mathrm{d})(p<0.05)$. Then 50 and 100 Lux of light intensity increased compared to $200 \mathrm{Lux}$ group $(p<$ 0.05). Among the milk compositions, milk fat percentage was higher in $100 \mathrm{Lux}(\mathrm{T} 2,4.35 \%)$, but was lower in $50 \mathrm{Lux}(\mathrm{T} 1,3.57 \%)$ and $200 \mathrm{Lux}(\mathrm{T} 3,3.70 \%)$ than in Control $(3.86 \%)(p<0.05)$. The contents of milk fat and total solids were higher at $100 \mathrm{Lux}$ (T2, milk fat $1.62 \mathrm{~kg}$ and total solids $4.91 \mathrm{~kg}$ per day) than at the others (milk fat 1.15 to $1.30 \mathrm{~kg}$, and total solids 3.94 to $4.57 \mathrm{~kg}$ per day) $(p<0.05)$.

Dairy farms use for the daily photoperiod and light intensity system as management tool to improve milk production. Dairy cows exposed to LDPP in lactation period produce more milk yield with 10 to $15 \%$ [10] or with $2.5 \mathrm{~kg} / \mathrm{cow}$ per day [6] compared to cows exposed to SDPP. Similar to previous studies, the present study also appeared to increase the milk yield with $15.9 \%$ at $50 \mathrm{Lux}$ and with $13.4 \%$ at $100 \mathrm{Lux}$ in longer photoperiod (16 h of light per day). The exposure to continuous light in the dark period does not have a positive effect on milk production of dairy cows [11]. In this regard, Buchanan et al. [36] suggested that a dark period is necessary to maintain the photoperiodic responses, since cows exposed in continuous lighting may be lost the ability to recognize the day length. Especially during the night intensity of dairy cows, Muthuramalingam et al. [2] reported less than 10 Lux, while Bal et al. [37] suggested 40 to 60 Lux.

The conflicting results were reported by previous studies on the milk composition obtained by the different photoperiod. Miller et al. [38] reported that milk composition was not affected by photoperiod management. Bodurov [8] found that milk fat content increased by $0.3 \%$ in LDPP, however, other studies reported milk fat percentage decreased to LDPP $[6,12]$. This study found that the milk fat content increased as milk yield increased to the LDPP conditions compared to the natural photoperiod, although it was difficult to identify the effect of the light intensity on milk fat percentage.

Some studies reported that cows exposed to LDPP increased by 0.8 to $1.5 \mathrm{~kg} / \mathrm{d}$ of DMI to support the higher milk production $[9,38]$. Prior to conducting this study, the DMI was expected to be higher as milk yield increased to the treatment groups, but in fact, DMI in the control group was higher. This result was supported by Peters et al. [10] reported that additional light and longer light period (16 h of 114 to 207 Lux vs. 9 or 12 h of 39 to 93 Lux) were increased both growth and milk yield without any increase in feed consumption. This could be explained that the time for intake and conversion of feed and the productivity are influenced at a higher extent by the physiological state and social hierarchy than by the photoperiod [39].

\section{Melatonin and cortisol concentrations of milk}

Milk melatonin and cortisol concentrations milked with AMS according to the milking time per 24-h are shown in Table 5. Melatonin is a neuro-hormone derived from serotonin during the dark phase, and produced particularly in the pineal gland, but also in the retina of vertebrates [40]. In this study, average daily melatonin level in milk was higher in treatment groups than in control, and increased to T3 $(28.20 \mathrm{pg} / \mathrm{mL}), \mathrm{T} 2(24.62 \mathrm{pg} / \mathrm{mL})$, and T1 $(19.78 \mathrm{pg} / \mathrm{mL})$ in order $(p<0.05)$. These results exhibited that the daily melatonin concentration in milk was high in LDPP than in natural photoperiod, and increased as the light intensity increased from 50 to 200 Lux. Milk melatonin level was different with the milking times that it was high at 08:01 to 12:00 h in Control, at 16:01 to 20:00 h in T1 and T2, at 20:01 to 24:00 h in T3 $(p<0.05)$. Vanecek [41] reported that the duration of melatonin increase was short on LDPPs and long on SDPPs. These results were different with the current study that the melatonin level in milk retained longer in T2 and T3 compared to milk melatonin level at 08:01 to 12:00 h in Control. Moreover, cortisol which is a hormone of glucocorticoid class, is sensitively responded to light with a distinct circadian rhythm, and is one of the most important stress indicators in mammals [42]. Cortisol concentration in milk 
Table 5. Melatonin and cortisol concentrations in milk of dairy cows milked with automatic milking system according to the milking time per 24-h

\begin{tabular}{|c|c|c|c|c|c|c|c|c|}
\hline \multirow{2}{*}{ Milking time (MT) } & \multirow{2}{*}{ Control } & \multirow{2}{*}{$\mathrm{T} 1$} & \multirow{2}{*}{ T2 } & \multirow{2}{*}{ T3 } & \multirow{2}{*}{ SEM } & \multicolumn{3}{|c|}{$p$-value } \\
\hline & & & & & & Treat & MT & Treat $\times$ MT \\
\hline \multicolumn{9}{|l|}{ Melatonin (pg/mL) } \\
\hline 04:01-08:00 & $19.18^{y}$ & $17.85^{z}$ & $24.73^{y}$ & $28.78^{x y}$ & 0.68 & $<0.001$ & & \\
\hline 08:01-12:00 & $25.64^{x}$ & $20.38^{x y}$ & $21.79^{z}$ & $26.35^{y z}$ & 0.62 & $<0.001$ & & \\
\hline $20: 01-24: 00$ & $19.01^{y}$ & $20.51^{x y}$ & $26.00^{x y}$ & $31.86^{w}$ & 0.80 & $<0.001$ & & \\
\hline Mean & $19.36^{c}$ & $19.78^{c}$ & $24.62^{b}$ & $28.20^{a}$ & 0.28 & $<0.001$ & 0.007 & $<0.001$ \\
\hline \multicolumn{9}{|l|}{ Cortisol (pg/mL) } \\
\hline 00:01-04:00 & $1,016.25^{y}$ & $777.78^{x y}$ & $906.81^{x}$ & $787.47^{y}$ & 15.51 & $<0.001$ & & \\
\hline $16: 01-20: 00$ & $1,004.45^{y}$ & $752.09^{y}$ & $889.90^{x y}$ & $884.99^{x}$ & 14.37 & $<0.001$ & & \\
\hline $20: 01-24: 00$ & $998.78^{y}$ & $831.69^{x}$ & $858.52^{x y z}$ & $780.69^{y}$ & 14.71 & $<0.001$ & & \\
\hline Mean & $1,011.14^{\mathrm{a}}$ & $790.65^{c}$ & $870.75^{b}$ & $840.63^{\mathrm{bc}}$ & 6.29 & $<0.001$ & 0.049 & $<0.001$ \\
\hline
\end{tabular}

Control, natural photoperiod; T1, LDPP (day : night = $16: 8$ h) with 50 Lux of the light intensity; T2, LDPP with 100 Lux; T3, LDPP with 200 Lux.

${ }^{a-c}$ Denote comparison made within row.

${ }^{w-z}$ Denote comparison made within column.

was higher in control than that in treatment groups (T1, T2, and T3) $(p<0.05)$. Average cortisol concentration was lowest in $\mathrm{T} 1$ exposed to $50 \mathrm{Lux}$ among the treatment groups under the LDPP condition of daytime from 04:30 to $20: 30 \mathrm{~h}(p<0.05)$.

\section{Biochemical indices in blood}

The biochemical indices level in blood of dairy cows exposed under the different light programs is shown in Table 6. The level of blood melatonin was lower in T2 (17.44 pg/mL) and T3 (17.03 pg/ $\mathrm{mL})$ than in Control $(25.55 \mathrm{pg} / \mathrm{mL})$ and T1 $(23.72 \mathrm{pg} / \mathrm{mL})(p<0.05)$. Melatonin is a relationship between blood and milk concentrations [41], since melatonin is amphiphilic, so it can freely diffuse through biological membranes into the circulatory system and from the bloodstream into the milk [43]. Kollmann et al. [44] found about $40 \%$ of the blood melatonin concentration in the milk of cows producing approximately $32 \mathrm{~kg} / \mathrm{milk} /$ day. However, this study showed a different tendency to melatonin level in blood collected at 14:00 h compared to milk milked at 12:01 to $16: 00 \mathrm{~h}$. Blood cortisol concentration decreased the treatment groups compared with the Control $(p<0.05)$. These results could be explained by previous studies $[45,46]$. Exposed to light stimulates the gene expression in adrenal gland causing plasma corticosterone surge in mammals [45]. Hyder et al. [46] suggested that melatonin may inhibit this gene expression to reduce cortisol secretion. Taken together, we consider that dairy cows may be produced more melatonin in body fluids under the LDPP than that under the SDPP, and then could relieve their stress.

Blood metabolites can indicate the energy and protein metabolism and liver health of the dairy cows [47]. In this study, blood urea nitrogen (BUN) level in blood was significantly increased for lactating dairy cows exposed to LDPP compared to those exposed to natural photoperiod. Creatinine level was showed the similar tendency to BUN, which is positively correlated with MUN and creatinine level [48]. Previous studies found that some blood metabolites were variable 
Table 6. Biochemical indices status in lactating dairy cows

\begin{tabular}{|c|c|c|c|c|c|c|}
\hline Item & Control & T1 & T2 & T3 & SEM & $p$-value \\
\hline Melatonin $(\mathrm{pg} / \mathrm{mL})$ & $25.55^{\mathrm{a}}$ & $23.72^{\mathrm{a}}$ & $17.44^{b}$ & $17.03^{b}$ & 0.78 & $<0.001$ \\
\hline Cortisol (pg/mL) & $1,437.61^{\mathrm{a}}$ & $1,224.31^{\mathrm{b}}$ & $953.03^{\mathrm{c}}$ & $935.52^{c}$ & 44.83 & $<0.001$ \\
\hline Total protein $(\mathrm{g} / \mathrm{dL})$ & 55.90 & 59.20 & 62.72 & 61.69 & 1.45 & 0.389 \\
\hline Albumin (g/dL) & 2.28 & 2.42 & 2.62 & 2.63 & 0.07 & 0.198 \\
\hline BUN (mg/dL) & $15.26^{b}$ & $17.94^{\mathrm{a}}$ & $18.54^{\mathrm{a}}$ & $19.36^{a}$ & 0.40 & 0.001 \\
\hline Creatinine $(\mathrm{mg} / \mathrm{dL})$ & 1.43 & 1.46 & 1.53 & 1.63 & 0.03 & 0.059 \\
\hline Glucose (mg/dL) & 49.83 & 49.17 & 51.92 & 49.33 & 0.77 & 0.590 \\
\hline Non-esterified fatty acid (mg/dL) & 42.92 & 29.58 & 31.92 & 34.25 & 3.25 & 0.531 \\
\hline Triglyceride (mg/dL) & 4.42 & 4.75 & 4.83 & 5.58 & 0.23 & 0.357 \\
\hline G-GTP (IU/L) & 18.58 & 24.58 & 26.83 & 24.58 & 2.73 & 0.768 \\
\hline GOT (AST) (IU/L) & 47.17 & 52.17 & 56.25 & 58.83 & 2.30 & 0.331 \\
\hline GPT (ALT) (IU/L) & $14.42^{c}$ & $18.08^{\mathrm{bc}}$ & $21.08^{\mathrm{ab}}$ & $24.08^{\mathrm{a}}$ & 0.83 & $<0.001$ \\
\hline Cholesterol (mg/dL) & 121.92 & 137.83 & 147.17 & 145.25 & 5.33 & 0.352 \\
\hline
\end{tabular}

The blood sample was collected via jugular venipuncture of each cow at 14:00 $\mathrm{h}$.

Control, natural photoperiod; T1, LDPP (day : night = $16: 8$ h) with 50 Lux of the light intensity; T2, LDPP with 100 Lux; T3, LDPP with 200 Lux.

${ }^{\mathrm{a}-\mathrm{c}}$ Denote comparison made within row.

BUN, blood urea nitrogen; GTP, guanosine triphosphate; GOT, glutamic oxalacetic transaminase; AST, aspartate aminotransferase; GPT, glutamic pyruvate transaminase; ALT, alanine aminotransferase.

for animals exposed to different light photoperiod and color $[28,49]$. On that reason, these studies suggested because cows exposed to long photoperiod might be attributed to greater feed intake. However, DMI in this study decreased to dairy cows exposed to LDPP than those exposed to natural conditions. Previous studies tried to explain the reason that milk yield and blood metabolites were higher for LDPP without increasing DMI $[10,28,39]$. Espinoza and Oba [28] suggested that the daily rhythms of blood metabolism may be altered by the circadian rhythms such as the lightdark cycle.

Dahl [50] suggested that the milk production of dairy cows increased at the height of about 91 $\mathrm{cm}$ above the stall floor at 150 Lux of light intensity, and also increased in LDPP, which is 16 to $18 \mathrm{~h}$ of light followed by 6 to $8 \mathrm{~h}$ of darkness in a 24-h period [6]. The results of this study showed that it will be effective in reducing stress on dairy cows and improving milk productivity and milk compositions (fat and protein) when the light conditions regulate to extend the photoperiod to $16 \mathrm{~h}$ at a LED intensity of 100 Lux in dairy farm, which has a AMS, compared to natural light conditions. The difference in the present study compared with previous studies may be due to the geographical and environmental differences. Latitude affects the incidence angle of solar radiation and the length of photoperiod. Daylight period is longest at the summer solstice and shortest at the winter solstice in the Northern Hemisphere [51]. Therefore, further research is needed to optimize the light conditions in order to improve the milk productivity of dairy cows housed in loose barn with AMS in consideration of Korea's geographical environment

\section{CONCLUSIONS}

This study discussed effects of light intensity and light period on yield and compositions of milk, stress related hormones and biochemical indices in Holstein dairy cows, which milked in AMS. The 50 and 100 Lux exposed dairy cows showed more milk yield than those of other groups. Also, the 100 Lux exposed dairy cows exhibited higher level of fat, protein and total solids in milk as compared to other group cows. The level of melatonin in milk was significantly increased as the 
light intensity increased. Whereas, the cortisol levels in milk was lower in treatment groups than in Control. Our results suggest that the difference of photoperiod and light intensity could act as external stimulation to the rhythmic pattern (metabolites) involved in alteration of hormones function, milk yield, and milk compositions. Additionally, these results of the study are considering the widespread use of photoperiod in dairy animal industry to increasing incidence of antioxidant levels. In recent, it has been reported that the regulation of circadian rhythms via photoperiod and light intensity significantly influences on the performance and physiology of dairy cows [52]. Ongoing study is evaluating on molecular mechanism and circadian pattern underlying how light intensity and light period affect the milk production and compositions.

\section{REFERENCES}

1. Dahl GE, Tao S, Thompson IM. Lactation biology symposium: effects of photoperiod on mammary gland development and lactation. J Anim Sci. 2012;90:755-60. https://doi. org/10.2527/jas.2011-4630

2. Muthuramalingam P, Kennedy AD, Berry RJ. Plasma melatonin and insulin-like growth factor-1 responses to dim light at night in dairy heifers. J Pineal Res. 2006;40:225-9. https://doi. org/10.1111/j.1600-079X.2005.00303.x

3. Pettersson $\mathrm{D}$, Wiktorsson $\mathrm{H}$. Illumination or guiding light during night hours in the resting area of AM-barns. In: Meijering A, Hogeveen H, de Koning CJAM, editors. Automatic milking-a better understanding. Wageningen: Wageningen Academic; 2004. p. 468-73.

4. Phillips CJC, Morris ID, Lomas CA, Lockwood SJ. The locomotion of dairy cows in passageways with different light intensities. Anim Welf. 2000;9:421-31.

5. Stanisiewski EP, Chapin LT, Ames NK, Zinn SA, Tucker HA. Melatonin and prolactin concentrations in blood of cattle exposed to 8, 16 or 24 hours of daily light. J Anim Sci. 1988;66:727-34. https://doi.org/10.2527/jas1988.663727x

6. Dahl GE, Buchanan BA, Tucker HA. Photoperiodic effects on dairy cattle: a review. J Dairy Sci. 2000;83:885-93. https://doi.org/10.3168/jds.S0022-0302(00)74952-6

7. Dahl GE, Petitclerc D. Management of photoperiod in the dairy herd for improved production and health.J Anim Sci. 2003;81:11-7. https://doi.org/10.2527/2003.81suppl_311x

8. Bodurov N. Effect of supplementary artificial illumination with visible rays on biochemical indices in the blood serum, milk yields and fertilization during lactation. Vet Med Nauki. 1979;16:58-65.

9. Collier RJ, Dahl GE, VanBaale MJ. Major advances associated with environmental effects on dairy cattle. J Dairy Sci. 2006;89:1244-53. https://doi.org/10.3168/jds.S0022-0302(06)72193-2

10. Peters RR, Chapin LT, Leining KB, Tucker HA. Supplemental lighting stimulates growth and lactation in cattle. Science. 1978;199:911-2. https://doi.org/10.1126/science.622576

11. Marcek JM, Swanson LV. Effect of photoperiod on milk production and prolactin of Holstein dairy cows.J Dairy Sci. 1984;67:2380-8. https://doi.org/10.3168/jds.S0022-0302(84)81586-6

12. Phillips CJC, Schofield SA. The effect of supplementary light on the production and behaviour of dairy cows. Anim Sci. 1989;48:293-303. https://doi.org/10.1017/S0003356100040290

13. Lee JS, Nam KT, Park SM, Son YS. Questionnaire study on the difficulties and improvements of the 6th industrialization dairy farm. J Dairy Sci Biotechnol. 2016;34:255-62. https://doi. org/10.22424/jmsb.2016.34.4.255

14. Jacobs JA, Siegford JM. Invited review: the impact of automatic milking systems on dairy cow management, behavior, health, and welfare. J Dairy Sci. 2012;95:2227-47. https://doi. org/10.3168/jds.2011-4943 
15. Gygax L, Neuffer I, Kaufmann C, Hauser R, Wechsler B. Restlessness behaviour, heart rate and heart-rate variability of dairy cows milked in two types of automatic milking systems and auto-tandem milking parlours. Appl Anim Behav Sci. 2008;109:167-79. https://doi.org/10.1016/ j.applanim.2007.03.010

16. Hagen K, Lexer D, Palme R, Troxler J, Waiblinger S. Milking of Brown Swiss and Austrian Simmental cows in a herringbone parlour or an automatic milking unit. Appl Anim Behav Sci. 2004;88:209-25. https://doi.org/10.1016/j.applanim.2004.03.005

17. Hopster H, Bruckmaier RM, Van der Werf JTN, Korte SM, Macuhova J, Korte-Bouws G, et al. Stress responses during milking; comparing conventional and automatic milking in primiparous dairy cows. J Dairy Sci. 2002;85:3206-16. https://doi.org/10.3168/jds.S00220302(02)74409-3

18. Wenzel C, Schönreiter-Fischer S, Unshelm J. Studies on step-kick behavior and stress of cows during milking in an automatic milking system. Livest Prod Sci. 2003;83:237-46. https://doi. org/10.1016/S0301-6226(03)00109-X

19. Helmreich S, Wechsler B, Hauser R, Gygax L. Effects of milking frequency in automatic milking systems on salivary cortisol, immunoglobulin A, somatic cell count and melatonin. Schweiz Arch Tierheilkd. 2016;158:179-86. https://doi.org/10.2527/jas.2012-5692

20. Wright JB, Wall EH, McFadden TB. Effects of increased milking frequency during early lactation on milk yield and udder health of primiparous Holstein heifers. J Anim Sci. 2013;91:195202. https://doi.org/10.2527/jas.2012-5692

21. Auchtung TL, Salak-Johnson JL, Morin DE, Mallard CC, Dahl GE. Effects of photoperiod during the dry period on cellular immune function of dairy cows. J Dairy Sci. 2004;87:3683-9. https://doi.org/10.3168/jds.S0022-0302(04)73507-9

22. Thomas AA, Thelen JT, Go AS, Surbrook T, Vanee MA, Althouse J. A dairy long day lighting success story: MI dairy increases production and cuts costs. Poster session presented at: 2017 ASABE Annual International Meeting; 2017; St. Joseph, MI.

23. VanZweden BJ, Thomas AA, Go AS, Surbrook TC. Expanded LED benefits through an automated long day lighting system at a 3x milking dairy farm. Poster session presented at: 2019 ASABE Annual International Meeting; 2019; St. Joseph, MI.

24. AOAC [Association of Official Analytical Chemists] International. Official methods of analysis of AOAC International. 16th ed. Arlington, VA: AOAC International; 1995.

25. Van Soest PJ, Robertson JB, Lewis BA. Methods for dietary fiber, neutral detergent fiber, and nonstarch polysaccharides in relation to animal nutrition.J Dairy Sci. 1991;74:3583-97. https:// doi.org/10.3168/jds.S0022-0302(91)78551-2

26. NRC [National Research Council]. Nutrient requirements of dairy cattle. 7th ed. Washington, DC: National Academy Press; 2001.

27. Zähner M, Schrader L, Hauser R, Keck M, Langhans W, Wechsler B. The influence of climatic conditions on physiological and behavioural parameters in dairy cows kept in open stables. Anim Sci. 2004;78:139-47. https://doi.org/10.1017/S1357729800053923

28. Espinoza OS, Oba M. Interaction effect of photoperiod management and dietary grain allocation on productivity of lactating dairy cows. Can J Anim Sci. 2017;97:517-25. https://doi. org/10.1139/CJAS-2016-0234

29. Yeh N, Chung JP. High-brightness LEDs—energy efficient lighting sources and their potential in indoor plant cultivation. Renew Sustain Energy Rev. 2009;13:2175-80. https://doi. org/10.1016/j.rser.2009.01.027

30. Lim DH, Kim TI, Kim HJ, Kim SB, Park SM, Park JH, et al. Effect of short-distance walking activity on milk production and metabolic status of lactating dairy cows. J Korean Soc Grassl 
Forage Sci. 2018;38:343-8. https://doi.org/10.5333/KGFS.2018.38.4.343

31. Armstrong D. Heat stress interaction with shade and cooling. J Dairy Sci. 1994;77:2044-50. https://doi.org/10.3168/jds.S0022-0302(94)77149-6

32. De Rensis F, Garcia-Ispierto I, López-Gatius F. Seasonal heat stress: clinical implications and hormone treatments for the fertility of dairy cows. Theriogenology. 2015;84:659-66. https:// doi.org/10.1016/j.theriogenology.2015.04.021

33. Ruckebusch Y.The relevance of drowsiness in the circadian cycle of farm animals. Anim Behav. 1972;20:637-43. https://doi.org/10.1016/S0003-3472(72)80136-2

34. Nilsson E. Quantification of sleep in dairy cows in three different stages of lactation. Alnarp: Swedish University of Agricultural Science; 2011.

35. Adamczyk K, Gil Z, Felenczak A, Skrzyński G, Zapletal P, Choroszy Z. Relationship between milk yield of cows and their 24-hour walking activity. Anim Sci Pap Rep. 2011;29:185-95.

36. Buchanan BA, Chapin LT, Tucker HA. Prolonged suppression of serum concentrations of melatonin in prepubertal heifers. J Pineal Res. 1992;12:181-9. https://doi.org/10.1111/j.1600079X.1992.tb00046.x

37. Bal MA, Penner GB, Oba M, Kennedy AD. Effects of dim light at night on milk yield, milk composition and endocrine profile of lactating dairy cows. Can J Anim Sci. 2008;88:609-12. https://doi.org/10.4141/CJAS07145

38. Miller ARE, Stanisiewski EP, Erdman RA, Douglass LW, Dahl GE. Effects of long daily photoperiod and bovine somatotropin (Trobest ${ }^{\circledR}$ ) on milk yield in cows.J Dairy Sci. 1999;82:171622. https://doi.org/10.3168/jds.S0022-0302(99)75401-9

39. Penev T, Radev V, Slavov T, Kirov V, Dimov D, Atanassov A, et al. Effect of lighting on the growth, development, behaviour, production and reproduction traits in dairy cows. Int J Curr Microbiol Appl Sci. 2014;3:798-810.

40. Tosini G, Fukuhara C. Photic and circadian regulation of retinal melatonin in mammals. J Neuroendocrinol. 2003;15:364-9. https://doi.org/10.1046/j.1365-2826.2003.00973.x

41. Vanecek J. Cellular mechanisms of melatonin action. Physiol Rev. 1998;78:687-721. https:// doi.org/10.1152/physrev.1998.78.3.687

42. Carlson LE, Campbell TS, Garland SN, Grossman P. Associations among salivary cortisol, melatonin, catecholamines, sleep quality and stress in women with breast cancer and healthy controls.J Behav Med. 2007;30:45-58. https://doi.org/10.1007/s10865-006-9082-3

43. Romanini EB, Volpato AM, Sifuentes dos Santos J, de Santana EHW, de Souza CHB, Ludovico A. Melatonin concentration in cow's milk and sources of its variation. J Appl Anim Res. 2019;47:140-5. https://doi.org/10.1080/09712119.2019.1583570

44. Kollmann MT, Locher M, Hirche F, Eder K, Meyer HHD, Bruckmaier RM. Effects of tryptophan supplementation on plasma tryptophan and related hormone levels in heifers and dairy cows. Domest Anim Endocrinol. 2008;34:14-24. https://doi.org/10.1016/ j.domaniend.2006.09.005

45. Ishida $A$, Mutoh T, Ueyama $T$, Bando $H$, Masubuchi $S$, Nakahara $D$, et al. Light activates the adrenal gland: timing of gene expression and glucocorticoid release. Cell Metab. 2005;2:297307. https://doi.org/10.1016/j.cmet.2005.09.009

46. Hyder I, Sejian V, Bhatta R, Gaughan JB. Biological role of melatonin during summer season related heat stress in livestock. Biol Rhythm Res. 2017;48:297-314. https://doi.org/10.1080/09 291016.2016.1262999

47. Cozzi G, Ravarotto L, Gottardo F, Stefani AL, Contiero B, Moro L, et al. Reference values for blood parameters in Holstein dairy cows: effects of parity, stage of lactation, and season of production.J Dairy Sci. 2011;94:3895-901. https://doi.org/10.3168/jds.2010-3687 
48. Nozad S, Ramin AG, Moghadam G, Asri-Rezaei S, Babapour A, Ramin S. Relationship between blood urea, protein, creatinine, triglycerides and macro-mineral concentrations with the quality and quantity of milk in dairy Holstein cows. Vet Res Forum. 2012;3:55-9.

49. Son J, Park J, Kang D, Belal SA, Cha J, Shim K. Effects of white, yellow, and blue colored LEDs on milk production, milk composition, and physiological responses in dairy cattle. Anim Sci J. 2020;91:e13337. https://doi.org/10.1111/asj.13337

50. Dahl GE. Let there be light: photoperiod management of cows for production and health. In: Proceedings of the 42nd Florida Dairy Production Conference; 2005; Gainesville.

51. Webster JR, Corson ID, Littlejohn RP, Stuart SK, Suttie JM. Photoperiodic requirements for rapid growth in young male red deer. Anim Sci. 1998;67:363-70. https://doi.org/10.1017/ S1357729800010146

52. Shehab-El-Deen MAMM, Fadel MS, Van Soom A, Saleh SY, Maes D, Leroy JLMR. Circadian rhythm of metabolic changes associated with summer heat stress in high-producing dairy cattle. Trop Anim Health Prod. 2010;42:1119-25. https://doi.org/10.1007/s11250-010-9534-1 